\title{
PREVENTIVE EFFECT OF FLAVIN ADENINE DINU- CLEOTIDE ON INDUCTION OF ADRENAL ATROPHY IN RAT BY DEXAMETHASONE
}

\author{
Shigeru OnO, Hiroko HiRANO, and Kijuro OBARA ${ }^{1}$ \\ Department of Biochemistry, School of Medicine, \\ Iwate Medical University, Morioka, Japan
}

(Received November 14, 1972)

An induction of adrenal atrophy in rat by dexamethasone phosphate was prevented to a considerable degree by intraperitoneal injection of flavin adenine dinucleotide.

Male Wistar strain rats weighing about $150 \mathrm{~g}$ were used.

Small amounts $(0.25 \mathrm{mg} / \mathrm{animal} /$ day $)$ and large amounts $(0.50 \mathrm{mg} / \mathrm{animal} / \mathrm{day})$ of dexamethasone phosphate were administered intraperitoneally once a day for 5 days to 2 groups of rats; experimental animals were sacrificed $6 \mathrm{hr}$ after final injection of the steroid hormone. Flavin adenine dinucleotide $(10 \mathrm{mg} / \mathrm{animal}$, Toa Eiyo Co., Japan) was administered intraperitoneally to 2 more groups of rats simultaneously with dexamethasone phosphate. The rats were sacrificed $6 \mathrm{hr}$ after the final injection of flavin adenine dinucleotide. After decapitation, the bilateral adrenals were excised, the surrounding tissues and adipose capsule removed, and the bilateral adrenals weighed.

The most striking effect of flavin adenine dinucleotide administration on the dexamethasone phosphate-treated rats was the prevention, to a considerable degree, of adrenal atrophy as shown in Table 1.

The weight of the adrenals of rats treated with the dexamethasone phosphate once a day for 5 successive days showed that the adrenals were atrophied to a far greater degree than those of the control rats. However, when flavin adenine dinucleotide was administered simultaneously in either large or small amounts of dexamethasone phosphate, the prevention of adrenal atrophy was significant $(p<0.01)$ as compared with the group not treated with flavin adenine dinucleotide.

Conventional measurements of thickness of adrenal cortex of rats used in this experiment were carried out (1). Cortical thickness was directly proportional to the adrenal weight of rat; the cortical atrophy, especially in the fascicular zone, was observed in rats treated with either small or large amounts of dexamethasone phosphate alone. However, the induction of cortical atrophy in rats treated with dexamethasone phosphate was partially prevented by the simultaneous admini1 小野 繁, 平野浩子, 小原喜重郎 
Table 1. Effect of flavin adenine dinucleotide (FAD) administration on the adrenal weight of rats treated with dexamethasone phosphate, for 5 days, in either large or small amounts.

\begin{tabular}{|c|c|c|c|c|}
\hline \multirow[b]{2}{*}{ Normal } & \multirow{2}{*}{$\begin{array}{c}\begin{array}{c}\text { Case of } \\
\text { No. }\end{array} \\
10\end{array}$} & \multicolumn{3}{|c|}{$\begin{array}{c}\text { Adrenal weight } \\
\text { (mg/kg body weight) }\end{array}$} \\
\hline & & $80.3 \pm 20.8^{\mathrm{a}}$ & - & \\
\hline $\begin{array}{l}\text { Dexamethasone } \\
\text { phosphate }\end{array}$ & 8 & $62.5 \pm 11.0$ & $P<0.05^{\mathrm{b}}$ & - \\
\hline$(0.5 \mathrm{mg} / \mathrm{animal} / \mathrm{day})$ & 8 & $43.8 \pm 15.0$ & & $P<0.01$ \\
\hline Normal & 10 & $80.3 \pm 20.8$ & - & \\
\hline $\begin{array}{l}\text { Dexamethasone } \\
\text { phosphate }\end{array}$ & 8 & $72.9 \pm 19.7$ & N.S ${ }^{b}$ & - \\
\hline (0.25 mg/animal/day) & 8 & $44.7 \pm 19.3$ & & $P<0.01$ \\
\hline
\end{tabular}

a standard deviation.

$\mathrm{b}$ in $t$-test, N.S: No significant.

c Flavin adenine dinucleotide was administered intraperitoneally to rats simultaneously with large or small amounts of dexamethasone phosphate.

stration of flavin adenine dinucleotide.

It is of interest that no significant differences in adrenal weight of rats were found between the normal group and the group treated simultaneously with flavin adenine dinucleotide and small amounts of dexamethasone phosphate.

This result suggests that induction of adrenal atrophy by long term oral corticoid therapy may be prevented partially by the administration of flavin adenine dinucleotide.

The authors gratefully acknowledge the histological measurement of adrenal cortex by Dr. K. Takayama, Department of Pathology, School of Medicine, Iwate Medical University.

\section{REFERENCE}

1) Sasano, H., Miyazawa, H., Shimizu, K., and Hirano, K., Folia Endocrinol. Jap., 42, 657 (1966). 